\title{
HUBUNGAN ASPIRASI EDUKASI ORANG TUA DENGAN PROSES PENGAMBILAN KEPUTUSAN KARIER SISWA DI SMA 36 JAKARTA
}

\author{
Puguh Adi Wibowo
}

?

?

\begin{abstract}
Abstrak:
Berdasarkan hasil pengolahan data antara variabel dihasilkan korelasi sebesar 0,601 dengan demikian ada hubungan positif kuat antar variabel, artinya bila variabel aspirasi edukasi orang tua meningkat atau ditingkatkan maka akan diikuti penguatan variabel pengambilan keputusan karier siswa. Nilai persamana regresi $\hat{Y}=50,719+0,514 X$ menujukan bahwa nilai murni atas variabel Proses pengambilan keputusan karier Siswa SMA Negeri 36 Jakarta Timur sebesar 50.719 sedangkan kontribusi variabel aspriasi edukasi orang tua sebesar 0,514 hasil uji hipotesis terlihat thitung 6,425>t tabel 1,980 maka (Ha) diterima dengan $\rho=0,000<\alpha=0,05$ dengan demikian variable aspriasi edukasi orang tua $(X)$ dinyatakan signifikan terhadap Proses Pengambilan Keputusan Karier (Y), sehingga hipotesis penelitian diterima, artinya variable Aspriasi Edukasi Orang Tua dapat dijadikan tolok ukur terhadap Proses Pengambilan Keputusan Karier.
\end{abstract}

Kata kunci: Keputusan Karier, Siswa SMA Negeri 36 Jakarta Timur

\section{Pendahuluan}

\section{Latar Belakang}

Proses pengambilan keputusan perlu dimengerti oleh lulusan SMA sewaktu akan memasuki perguruan tinggi, karena melalui tahap-tahap tersebut keputusan yang akan diambilnya akan lebih efektif. Mau Ke mana Setelah SMA? Pada kenyataannya, pembuatan pilihan (choice making) memiliki banyak dimensi, dan dampak. Memilih merupakan bagian dari suatu upaya pemecahan masalah sekaligus sebagai bagian dari proses pengambilan keputusan (decision making). Dampak penetapan pilihan akan membawa pengaruh jangka pendek/panjang, baik berupa keuntungan yang diperoleh maupun resiko yang mesti di- tanggung. Lebih-lebih penetapan pilihan dalam memilih perguruan tinggi, merupakan keputusan yang berdampak masa depan bagi seseorang. Colly menyatakan penyediaan bimbingan yang mampu menjawab lebih praktis dan rasional dapat membantu konseli dalam membuat pilihan karier yang tepat .

Hasil penelitian salah seorang guru BK di SMA Negeri 1 Rancaekek mengemukakan bahwa hampir 40\% siswa keberatan dengan jurusan dan sekolah yang mereka pilih. Contoh kasusnya sebagai berikut, (1) Ada siswa yang salah memilih jurusan. Banyak siswa yang bakat dan minatnya di IPA, tetapi karena akhir-akhir ini diberlakukan standar kelulusan yang tiap tahun semakin naik nilainya maka banyak

\footnotetext{
Mahasiswa Jurusan Bimbingan dan Konseling FIP UNJ,

Dosen Bimbingan dan Konseling FIP UNJ

3 Dosen Bimbingan dan Konseling FIP UNJ
} 
siswa IPA ramai-ramai pindah ke IPS. Akan tetapi, sebagian dari mereka jenuh karena tidak berniat untuk menghafal dan banyak juga yang mengeluhkan belajar akutansi; (2) Ada siswa yang bingung memilih jurusan maupun memilih perguruan tinggi yang faforit baik itu swasta ataupun negeri; (3) Ada siswa yang bingung mengeluhkan bagaimana keadaan dunia kerja dan pekerjaan apa yang layak mereka terima ketika seusai menyelesaikan studi di bangku SMA. Hal ini dikarenakan semakin ketatnya persaingan di dunia kerja itu sendiri

Bila mencermati hasil wancara dengan siswa dan guru dalam pra penelitian menujukan bahwa proses keputusan memilih merupakan salah satu bagian dari suatu pengambilan keputusan, maka tahaptahapnya perlu dipahami. Proses pengambilan keputusan meliputi : penetapan tujuan, pembatasan dan analisa masalah, mencari beberapa alternatif, memilih alternatif yang maksimal, pelaksanaan keputusan, serta penilaian dan monitoring.

Proses pengambilan keputusan perlu dimengerti oleh lulusan SMA, keputusan ke depan bagi siswa SMA baik pilihan atas penentuan pendidikan lanjutan (perguruan tinggi) atau pilihan lainnya tentunya atas pertimbangan orang tua, mengingat orangtua sangat berperan dan bertanggung jawab terhadap pendidikan anak dukungan dan dorongan dari keluarga serta lingkungan disekitarnya, agar mencapai otonomi atas diri sendiri. Pada saat ini peran orangtua dan respon dari lingkungan sangat diperlukan bagi siswa sebagai "penguat" untuk pengambilan keputusan untuk memastikan apa yang menjadi pilihan kelak setelah lulusan SMA

Dengan demikian orang tua bertanggung jawab mengatur, mengendalikan dan membimbing serta memperkenalkan nilai dan norma sejak kanakkanak, berbagai upaya aspirasi edukasi dilakukan orangtua terhadap anak. Aspirasi edukasi yang terjadi antara orangtua dengan siswa merupakan kegiatan yang diarahkan untuk mencapai tujuan pendidikan tertentu. Melalui aspirasi tersebut siswa berkesempatan untuk meningkatkan kematangan emosi dan kemampuan kognisinya, belajar, memahami dan mematuhi kebiasaan yang berlaku dalam keluarga, lingkungan, belajar menghargai orang lain dan menyesuaikan diri dengan lingkungannya serta belajar menyelesaikan tugas-tugas.
Berkenaan dengan permasalahan tersebut penulis tertarik untuk membuat penelitian dengan judul "Hubungan Aspirasi Edukasi Orang Tua dengan Proses Pengambilan Keputusan Karier Siswa di SMA 36 Jakarta"

\section{Identifikasi Masalah}

Berdasarkan latar belakang masalah yang telah diuraikan sebelumnya, maka identifikasi masalah dalam penelitian ini adalah :

1. Kebimbangan siswa untuk memilih atau menentukan karier selanjutnya pasca SMA mendatang

2. Kurangnya pengetahuan anak terhadap jurusan di perguruan tinggi dan jenjang karier lainnya pasca kelulusan mendatang.

3. Kurangnya materi bimbingan konseling karier bagi siswa dalam penentuan jurusan dan pilihan perguruan tinggi.

4. Kurangnya pengetahuan orang tua terhadap kepeminatan anak untuk melanjutkan karier mendatang khususnya terhadap pemilihan jurusan atau perguruan tinggi yang dituju.

5. Kurang pahamnya aspirasi edukasi orang tua dalam mendukung pengambilan keputusan bagi anak terhadap pilihan karier ?

\section{Pembatasan Masalah}

Mengingat luasnya cakupan masalah mengenai kinerja guru serta adanya keterbatasan waktu, biaya, dan tenaga, maka masalah penelitian ini akan dibatasi pada :

1. Variabel yang diamati adalah Aspirasi edukasi orang tua dan proses pengambilan keputusan karier

2. Subyek penelitian Sekolah Menengah Atas Negeri 36 Jakarta Timur

3. Obyek penelitian adalah siswa kelas III SMU 36 Jakarta Timur

\section{Perumusan Masalah}

Berkenaan dengan latar belakang masalah, identifikasi masalah dan pembatasan masalah maka rumusan masalah dalam penelitian ini adalah "Bagaimana hubungan spirasi Edukasi Orang Tua dengan Proses Pengambilan Keputusan Karier Siswa di SMA 36 Jakarta? 


\section{Tujuan Penelitian}

Tujuan penelitian adalah untuk mengetahui hubungan spirasi Edukasi Orang Tua dengan Proses Pengambilan Keputusan Karier Siswa di SMA 36 Jakarta.

\section{Landasan Teori}

\section{A. Deskripsi Teoritis}

\section{Aspirasi}

Aspirasi adalah: proses dimana individu memilih, mengorganisasi dan menginterprestasikan masukan-masukan ke dalam gambaran dunia yang memiliki arti. Menurut Charles adalah: proses di mana kita memilih, mengatur dan menginterprestasikan rangsangan tersebut ke dalam gambaran yang memberi makna dan melekat.

Menurut Hawkins aspirasi adalah "Information processing is a series of activities by which stimuli are perceived, transformed into information and stored. A useful information processing model having for major steps of stages : exposure, attention, interpretation, and memory. The first three of these constitute perception" artinya pengolahan informasi merupakan aktivitas didalam stimuluis / dorongan diterima, ditrasformatikan menjadi informasi dan disimpan, model Informasi yang berguna memiliki empat tahapan, tahapan pertama; pengungkapan, perhatian, interpretasi dan memori atau ingatan, tiga yang pertama di antaranya merupakan persepsi

Aspirasi menurut penulis adalah satu rangkaian komunikasi, dimana komunikasi orang dapat mempengaruhi dan merubah sikap orang lain. Komunikasi memungkinkan pemindahan, penyebaran ide atau penemuan baru kepada orang lain dalam proses pembentukan.

\section{a. Aspirasi Edukasi}

Berdasarkan definisi diatas menunjukan bahwa Aspirasi mempunyai hubungan sangat erat dengan keinginan yang dimiliki oleh setiap orang, Keinginan yang dimiliki bukan hanya untuk masa kini, tetapi juga menyangkut masa depannya. Aspirasi merupakan tujuan yang ditetapkan oleh individu berkaitan dengan suatu tugas yang mempunyai arti penting bagi dirinya atau menuntut pelibatan individu sepenuhnya arti pencapaian tujuan yang telah ditetapkan oleh individu memerlukan usaha yang maksimal dari individu . Di samping itu tujuan yang ditetapkan bukan sekedar merupakan keinginan tetapi biasanya merupakan sesuatu yang berarti baginya, dan dianggap sebagai tugas, sehingga individu yang bersangkutan akan berusaha keras untuk meraihnya. Berkenaan dengan definisi-definisi di atas maka aspirasi adalah tujuan atau sasaran yang ingin dicapai dan memiliki arti penting bagi individu serta memungkinkan untuk dicapai olehnya.

b. Aspirasi Edukasi Orangtua

Tujuan pendidikan dan cara pendidikan harus bersandar pada kesepakatan antara kedua orangtua.. Tentunya orangtua yang bertanggung jawab ingin anaknya sedapat mungkin mendekati kesempurnaan. Orangtua ingin siswabisa dibanggakan dari semua aspek.

Siswa akan belajar dari latihan-latihan dasar mengembangkan sikap-sikap sosial yang baik, kebiasaan-kebiasaan bertingkah laku yang memudahkan terbentuknya perilaku tanpa keraguan, tanpa pertarungan motif dan konflik yang terlalu lama di mana : (1) Dalam ikatan keluarga yang akrab dan hangat, seorang siswa yang memperoleh pengertian tentang hak, kewajiban, tanggung jawab yang diharapkan. Dalam keluarga siswa belajar mengenai kewibawaan dan sikap otoriter dari yang lebih tua. Siswa belajar mematuhi peraturan, tata cara keluarga. Mungkin juga terjadi penyalahgunaan otoritas, dimana orangtua yang terlalu ketat mengakibatkan berkurangnya dinamika siswa dalam mengembangkan kemampuan dan kepribadiannya. Di dalam keluarga dimana ada hubungan yang baik antara anggotanya, siswa belajar bekerja sama, membagi rasa kepada yang lainnya, selalu ingat akan adanya saudara-saudara sehingga membentuk sikapsikap sosial yang memudahkan hubungan sosial. Seorang siswa dalam keluarga terlihat ikatan keluarga yang diwarnai kehangatan dan keakraban akan membentuk azas hidup berkelompok yang baik sebagai landasan hidupnya di masyarakat. (2) Bilamana menghadapi seseorang dalam pergaulan yang santai dan menganggap hidup itu selalu membahagiakan, akan diketahui bahwa latar 
belakang kehidupan keluarganya, menyebabkan ia selalu melihat sisi positif dalam kehidupannya. Sebaliknya seseorang yang selalu tegang dan pesimis dalam pandangan hidupnya, disebabkan latar belakang keluarganya yang dikuasai oleh suasana suram .

\section{c. Faktor-faktor Yang Mempengaruhi Aspirasi Edukasi}

Hurlock membagi empat faktor dalam aspirasi edukasi, yaitu:

1) Tingkah laku atau sasaran yang diinginkan oleh individu. Individu mempunyai keinginan atau harapan dalam hidupnya di mana harapan itu merupakan suatu hal yang sangat penting dan berarti bagi dirinya. Harapan itu bisa macam-macam bentuknya, misalnya harapan dalam bidang pendidikan, pekerjaan kesehatan, dan sebagainya. Atau harapan-harapan yang ingin dicapainya.

2) Perkiraan tentang suatu hal yang dapat dilakukan atau dicapainya. Harapan itu bukan semata merupakan harapan belaka tetapi individu mengharapkan hal tersebut, karena memperkirakan akan meraihnya atau melakukannya dan berusaha untuk meraihnya. Harapan tersebut mempunyai suatu titik batas atau target yang hendak dicapai. Penetapan ini biasanya mempertimbangkan berbagai macam faktor atau kondisi yang ada seperti kemampuannya, ekonominya, lingkungannya dan sebagainya.

3). Penilaian pentingnya hasil tersebut bagi individu. Tercapainya harapan atau keinginan yang diperkirakan mampu diraihnya atau ditargetkannya akan memberikan keputusan. Dikatakan harapan atau target itu bernilai baginya atau mempunyai nilai khusus bagi individu karena akan memberikan kepuasan.

Dari pengertian tersebut dapat disimpulkan bahwa aspirasi edukasi orangtua yang baik diikuti dengan pola pendidikan yang tepat akan sangat berpengaruh terhadap komunikasi anaknya, terutama dalam bidang pendidikan.

\section{Bimbingan Karier}

a. Pengertian Bimbingan Karier
Bimbingan karir merupakan salah satu jenis bidang bimbingan dalam Bimbingan dan Konseling. Para siswa memperoleh informasi mengenai karir dari Guru Pembimbing melalui layanan Bimbingan Karir. Secara umum tujuan bimbingan karir di sekolah adalah untuk membantu siswa memiliki keterampilan dalam mengambil keputusan mengenai karir dimasa depan.

Peran bimbingan dan konseling karir sebagai pengintegrasi berbagai kemampuan dan kemahiran intelektual dan keterampilan khusus hingga sampai pada kematangan karir secara spesifik terumus dalam tujuan bimbingan karir sebagai berikut:

1) Peserta didik dapat mengenal (mendeskripsikan) karakteristik diri (minat, nilai, kemampuan, dan ciri-ciri kepribadian) yang darinya peserta didik dapat mengidentifikasi bidang studi dan karir yang sesuai dengan dirinya.

2) Peserta didik memperoleh pemahaman tentang berbagai hal terkait dengan dunia (karir-studi) yang akan dimasukinya seperti tingkat keluasan karir yang ditawarkan, deskrisi tugas dalam berbagai bidang pekerjaan, pengaruh perkembangan teknologi terhadap bidang kerja tertentu, kontribusi yang dapat diberikan dalam bidang pekerjaan tertentu pada masyarakat, dan tuntutan kemampuan kerja dalam bidang-bidang pekerjaan tertentu di masa depan.

3) Peserta didik mampu mengidentifikasi berbagai bidang pendidikan yag tersedia yang relevan dengan berbagai bidang pekerjaan. Dengan demikian peserta didik memperoleh dan dapat menerapkan pengetahuan dan keterampilan (skill) yang dituntut oleh peran-peran kerja tertentu.

4) Peserta didik mampu mengambil keputusan karir bagi dirinya sendiri, merencanakan langkah-langkah konkrit untuk mewujudkan perencanaan karir yang realistik bagi dirinya. Perencanaan karir yang realistik akan meminimalkan faktor dan dampak negatif dan memaksimalkan faktor dan dampak positif dari proses pemilihan karir.

5) Mampu menyesuaikan diri dalam mengimplementasikan pilihannya dan berfungsi optimal dalam karir (studi dan kerja). 


\section{b. Tujuan Bimbingan Karier}

Tujuan Bimbingan Karier adalah membantu para siswa agar:

1) Para siswa dapat memahami dan menilai dirinya sendiri ,terutama yang berkaitan dengan segi potensi yang ada dalam dirinya,mengenai kemampuan, minat,bakat,sikap,cita-citanya.

2) Menyadari dan memahami nilai-nilai yang ada dalam dirinya,serta yang ada dalam masyarakat.

3) Mengetahui berbagai jenis pekerjaan yang berhubungan dengan potensi yang ada dalam dirinya ,mengetahui jenis-jenis pendidikan dan latihan yang diperlukan bagi suatu bidang tertentu, memahami hubungan usaha dirinya yang sekarang dengan masa depannya.

4) Menemukan hambatan-hambatan yang mungkin timbul yang disebabkan oleh dirinya sendiri dan faktor lingkungan serta mencari jalan untuk dapat mengatasi hambatan-hambatan tersebut.

5) Para siswa dapat merencanakan masa depannya serta menekan karier dan kehidupannya yang serasi ,yang sesuai.

Sehingga tidaklah mungkin siswa dapat menentukan karir tanpa bantuan dan bimbingan dari konselor, karena disadari atau tidak untuk dapat memahami kemampuan diri siswa tidaklah mungkin muncul dengan sendirinya, akan tetapi diperlukan bimbingan dan arahan dari konselor.

\section{c. Pengambilan Keputusan Karier}

Pengambilan keputusan yang dilakukan oleh remaja sama pentingnya dengan pengambilan keputusan yang dilakukan oleh dewasa. Keputusan pengambilan jurusan ketika di SMA sangat berpengaruh terhadap masadepan mereka. Merupakan awal dari pengambilan keputusan karier itu sendiri, karenanya remaja SMA seharusnya dapat mengambil keputusan yang tepat, karena akan mempengaruhi masa depan mereka. Namun,seringkali remaja merasa bingung dan bimbang dengan pilihan karier mereka, karena itulah remaja membutuh kandukungan dari keluarga mereka .

Hubungan yang harmonis dan interaksi yang baik antar orang tua dengan anak membantu rema- ja dalam mengambil keputusankarier mereka. Bagi siswa SMA, pengambilan keputusan karir yang termasuk penting adalah keputusan untuk memilih program studi, sedangkan pada saat itu banyak siswayang belum memunyai kematangan untuk itu .

\section{d. Teori CIP (Cognitive Information Processing)} dan Pendekatan Pendekatan CASVE

Tujuan pendekatan CIP adalah untuk membantu individu membuat suatu pilihan karier saat ini yang tepat dan belajar meningkatkan keterampilan pemecahan masalah serta pengambilan keputusan yang diperlukan untuk pilihan-pilihan di masa mendatang. Pendekatan CIP memungkinkan para konselor untuk secara terus-menerus menangani permasalahan-permasalahan karier konseli saat ini dan juga mengajari mereka keterampilan untuk membuat keputusan karier selama rentang kehidupan.

Peterson menggambarkan konstruk-konstruk CIP sebagai seperangkat lingkaran-lingkaran konsentris yang meluas. Seorang individu bergerak dari lingkaran yang paling dalam, suatu permasalahan karir, melalui serangkaian konstruk, ruang permasalahan, pemecahan masalah, pengambilan keputusan karir, dan pengembangan karir, pada suatu lingkaran yang luas dan mencakup keseluruhan prestasi dari suatu gaya hidup .

Pendekatan CIP membantu perkembangan klien ke arah suatu "solusi optimal". Proses tersebut dimulai dengan suatu pemahaman akan diri dan pekerjaan. Dua basis pengetahuan diri dan pekerjaan, mendasarkan proses-proses meta-kognitif dari pengambilan keputusan

CASVE sebagai pendekatan proses pengambilan keputusan karier (career-decision making) mempunyai lima komponen yang saling berkaitan yaitu sebagai berikut. Komunikasi (communication). Tahap ini dimulai ketika seseorang menyadari adanya suatu masalah (problem) dan sedang merasakan adanya masalah tersebut. Seseorang merasakan atas kebutuhan untuk membuat suatu pilihan yang baik dan ingin belajar bagaimana cara yang harus dilakukannya, yang didorong oleh adanya kesenjangan antara kebimbangan disatu pihak. Seseorang menjadi tegang atas keadaan yang dihadapinya, atas kon- 
disi yang terjadi saat ini dengan kondisi yang diinginkan.

Analisis (analysis). Pada tahap ini seseorang memahami adanya hubungan timbal balik antar komponen yang terlibat dalam suatu masalah (problem). Mengapa masalah terjadi, dan bagaimana cara memecahkannya. Untuk kepentingan ini diperlukan pemahaman diri (minat, kapabilitas, nilai-nilai dan sikap), dan pemahan tentang kondisi karier (ragam karier, peluang, kelebihan dan kelemahan) merupakan informasi yang sangat dibutuhkan.

Sintesis (synthesis). Tahap ini meliputi dua fase, yaitu fase elaborasi (elaboration) dan fase kristalisasi (crystallization). Pada fase elaborasi, seseorang mengidentifikasi beberapa alaternatif yang berkembang dan potensial, sedangkan pada fase kristalisasi individu melakukan proses untuk membatasi alternatif yang sedang dikaji untuk dibuat suatu daftar pilihan-pilihan.

Menilai (valuing). Pada tahap ini, seseorang melakukan kajian atau alternatif (daftar pilihan pekerjaan, program studi atau pendidikan karier atau job) yang dikaitkan dengan sistem nilai, dan membuat suatu prioritas alternatif yang dipilih. Untuk melakukan penilaian digunakan kriteria atau tolok ukur tertentu yang dapat diterima oleh sistem nilai masyrakat.

\section{B. Kerangka Berfikir}

Masa remaja merupakan masa di mana pengambilan keputusan meningkat. Remaja mulai mengambil keputusan-keputusan tentang masa depan, seperti memilih bidang karier. Remaja sering memandang eksplorasi karier dan pengambilan keputusan dengan kebimbangan, ketidakpastian, dan stres. Hal ini didukung dengan fakta di lapangan yang menujukkan bahwa kebanyakan remaja menga-lami kebingungan ketika ditanya tentang rencana karier yang akan dipilih.

Bimbingan karir merupakan salah satu jenis bidang bimbingan dalam Bimbingan dan Konseling. Para siswa memperoleh informasi mengenai karir dari Guru Pembimbing melalui layanan Bimbingan Karir. Secara umum tujuan bimbingan karir di sekolah adalah untuk membantu siswa memiliki keterampilan dalam mengambil keputusan mengenai karir di masa depan.
Kemampuan remaja dalam pengambilan keputusan memiliki konsekuensi yang sama dengan orang dewasa karena mempunyai dampak yang penting sesuai dengan resikonya. Sedangkan proses perjalanan dalam pemilihan karier sewaktu di SMA dapat dilihat saat mereka harus memilih jurusan sekolah, apakah mengambil jurusan IPA, IPS atau Bahasa. Menurut Hurlock (2009: 207) masa remaja merupakan masa yang sangat berhubungan dengan penentuan kehidupan di masa depan, karena perilaku dan aktivitas yang dilakukan pada masa remaja menjadi masa awal dalam mengukir kehidupan yang lebih baik di masa depan mereka.

Masa remaja sebagai salah satu fase dalam kehidupan manusia, menuntut remaja untuk memenuhi tugasnya dalam memilih karier dan menentukan karier. Tugas perkembangan karier menurut Havighurt yaitu mampu memilih dan mempersiapkan kariernya. Tugas tersebut bertujuan memilih suatu pekerjaan yang sesuai dengan kemampuan dan mempersiapkan diri, memiliki pengetahuan tentang suatu pekerjaan

Pengambilan keputusan yang dilakukan oleh remaja sama pentingnya dengan pengambilan keputusan yang dilakukan oleh orang dewasa. Keputusan pengambilan jurusan ketika di SMA sangat berpengaruh terhadap masa depan mereka. Merupakan awal dari pengambilan keputusan karier itu sendiri, karenanya remaja SMA seharusnya dapat mengambil keputusan yang tepat,k arena akan mempengaruhi masa depan mereka. Namun,seringkali remaja merasa bingung dan bimbang dengan pilihan karier mereka, karena itulah remaja membutuh dukungan dari keluarga mereka. Hubungan yang harmonis dan interaksi yang baik antar orang tua dengan anak membantu remaja dalam mengambil keputusan karier mereka.

Banyak orang tua menjadi orang tua tanpa mengalami persiapan untuk menjadi orangtua. Kebanyakan orangtua hanya menjadi orangtua berintikan naluri saja, tanpa mempersiapkan diri untuk menjadi seorang ayah atau seorang ibu. Banyak cara mendidik mengikuti pola pendidikan yang dialaminya dengan kemungkinan hasil yang dijadikannya sama seperti yang diterapkan pada zaman yang berbeda. Maka dapat dimengerti bahwa orangtua sering mencoba-coba berbagai cara terhadap anak. Seolah-olah 
siswa menjadi kelinci percobaan dalam usaha pendidikan. Akhirnya terlihat bahwa orangtua yang memiliki cukup biaya pendidikan bagi anaknya, mengirim siswa/i mencecap pendidikan di luar negeri atau pusat-pusat pendidikan yang memiliki gengsi, namun ternyata pendidikan tersebut tidak terlalu menghasilkan apa yang diharapkan orangtua.

Bagi siswa SMA, pengambilan keputusan karir yang termasuk penting adalah keputusan untuk memilih program studi, sedangkan pada saat itu banyak siswa yang belum mempunyai kematangan untuk itu. Belum matangnya putusan pilihan program studi di antara siswa dapat disebabkan oleh faktorfaktor internal dan eksternal. Faktor-faktor eksternal antara lain keluarga dan sekolah. Dalam usia remaja tersebut, siswa SMA dituntut untuk mempersiapkan diri memasuki dunia kerja, dan masa SMA merupakan waktu untuk belajar menyiapkan masa depan di mana siswa diharapkan untuk dapat mengambil tindakan yang mandiri dan menerima tanggung jawab atas keputusan mereka .

Menurut Hartinah (2010), dalam proses perkembangan karir, remaja sering mengalami hambatan. Masalah yang berasal dari dalam dirinya antara lain ketidakyakinan individu terhadap kemampuan yang dimiliki untuk mencapai suatu hasil atau pilihan karir yang diinginkan, dan masalah yang berasal dari luar atau lingkungan antara lain sering terjadi orang tua yang memaksa anaknya untuk memilih jurusan pendidikan yang mempersiapkan pada pekerjaan tertentu tetapi tidak sesuai dengan kemampuan anak. Yang lebih parah lagi kalau terjadi pilihan anak dan pilihan orang tua tidak saling mendukung, maka anak menghadapi konflik yang lebih serius lagi dalam memilih karirnya.

\begin{tabular}{|l|l|}
\hline ASPIRASI EDUKASI & \multicolumn{1}{|l|}{$\begin{array}{l}\text { PROSES PENGAMBILAN } \\
\text { ORANG TUA }\end{array}$} \\
$\begin{array}{ll}\text { 1. Minat } \\
\text { 2. Latar Belakang }\end{array}$ & $\begin{array}{l}\text { 1. Mendeskripsikan } \\
\text { 3. Status Ekonomi } \\
\text { 4. Sosial Budaya }\end{array}$ \\
\hline
\end{tabular}

\section{Hipotesis}

Hipotsis merupakan pendugaan sementara, adapun hipotesis dalam penelitian ini adalah :

$$
\mathbf{H}_{0}: \rho \mathbf{y}_{\bullet}=\mathbf{0}
$$

Tidak ada hubungan Aspirasi Edukasi Orang Tua dengan Proses Pengambilan Keputusan Karier pada siswa di SMA 36"

$\mathrm{H}_{1}: \rho \mathrm{y}_{.}>\mathbf{0}$

Ada hubungan Aspirasi Edukasi Orang Tua dengan Proses Pengambilan Keputusan Karier pada siswa di SMA 36"

\section{Metode Penelitian}

\section{A. Metode Penelitian}

Metode penelitian yang digunakan dalam penelitian ini adalah metode survey dengan pendekatan korelasional dan menggunakan data primer (variabel bebas) dan data sekunder (variabel terikat). Penggunaan metode tersebut dimaksudkan untuk mengukur derajat keeratan antara; hubungan persepsi Siswa di SMA 36 Jakarta terhadap Aspirasi Edukasi Orang Tua dan hubungan persepsi Siswa terhadap Proses Pengambilan Keputusan Karier Siswa di SMA 36 Jakarta.

\section{B. Populasi dan Teknik Pengambilan Sampel \\ 1. Populasi}

Populasi merupakan wilayah generalisasi yang terdiri atas obyek/subyek yang mempunyai kualitas dan karakteristik tertentu yang ditetapkan oleh peneliti untuk dipelajari dan kemudian ditarik kesimpulan, dengan demikian obyek yang menjadi kajian dalam penelitian Siswa Kelas XII SMA 36 Jakarta sebanyak 9 Kelas dengan jumlah siswa sebanyak 298 Siswa.

2. Sampel

Sampel adalah bagian dari jumlah dan karakteristik yang dimiliki oleh populasi tersebut. Dalam penentuan teknik sampling penulis menggunakan probabiliti sampling dimana sampel menggunakan sistem acak (random sampling). Sampel $=75$ Orang Siswa

\section{Instrumen Penelitian}

Penelitian ini menggunakan dua variabel yakni Aspirasi Edukasi Orang Tua yang merupakan variabel independen dependen (X) dan variabel dependen atau variabel terikat dalam penelitian ini adalah Proses Pengambilan Keputusan Karier (Y) 


\section{Aspirasi Edukasi Orang Tua}

a. Definisi Konseptual

Aspirasi proses di mana individu memilih, mengorganisasi dan menginterprestasikan masukan-masukan ke dalam gambaran dunia yang memiliki arti sehingga Aspirasi edukasi orangtua adalah proses dimana orangtua (ayah dan atau ibu) memilih, mengatur dan menginterprestasikan rangsangan tersebut ke dalam gambaran yang memberi makna dan melekat.

b. Definisi Operasional

Tanggapan responden mengenai pendidikan siswa lebih didasarkan pada sikap siswa terhadap sekolah, dengan demikian sikap siswa terhadap sekolah terutama dipengaruhi oleh orangtuanya, yang diskor melalui aspek-aspek kepeminatan, latar belakang budaya, status ekonomi dan status budaya. Sedangkan indikatornya terdiri dari kemampuan, pengetahuan anak, laki-laki dan perempuan, motivasi, bakat, disiplin, pergaulan, mampu, kurang mampu, tidak mampu, dan lingkungan sosial.

\section{Proses Pengambilan Keputusan Karier}

a. Definisi Konseptual

Proses pengambilan keputusan karier adalah berdasarkan asumsi mengenai pilihan karier yang diekspresikan atau diungkapkan melalui kepribadian seseorang.

b. Definisi Operasional

Dimensi pengambilan keputusan karir adalah suatu proses sistematis mengenai pilihan karir yang telah ditetapkan individu, dengan dimensi peserta didik dapat mengenal (mendeksripsikan) memperoleh pemahaman, mampu mengidentifikasi berbagai bidang dan merencanakan langkah kongkrit

\begin{tabular}{|c|c|c|}
\hline VARIABEL & ASPEK & INDIKATOR \\
\hline \multirow{4}{*}{$\begin{array}{l}\text { ASPIRASI } \\
\text { EDUKASI }\end{array}$} & Minat & $\begin{array}{l}\text { Kemampuan } \\
\text { Pengetahuan } \\
\text { anak } \\
\text { Motivasi } \\
\text { Bakat }\end{array}$ \\
\hline & Latar Belakang & $\begin{array}{l}\text { Disiplin } \\
\text { Sekolah }\end{array}$ \\
\hline & Status Ekonomi & $\begin{array}{l}\text { Mampu } \\
\text { Kurang Mampu } \\
\text { Tidak Mampu }\end{array}$ \\
\hline & Sosial budaya & $\begin{array}{l}\text { Lingkungan } \\
\text { Sosial }\end{array}$ \\
\hline \multirow{4}{*}{$\begin{array}{c}\text { Proses } \\
\text { Pengambilan } \\
\text { Keputusan } \\
\text { Karier }\end{array}$} & $\begin{array}{l}\text { peserta didik } \\
\text { dapat mengenal } \\
\text { (mendeskripsikan) }\end{array}$ & $\begin{array}{l}\text { Minat } \\
\text { Nilai } \\
\text { Kemampuan } \\
\text { Keperibadian }\end{array}$ \\
\hline & $\begin{array}{l}\text { memperoleh } \\
\text { pemahaman }\end{array}$ & $\begin{array}{l}\text { Tingkat } \\
\text { keluasan karier }\end{array}$ \\
\hline & $\begin{array}{l}\text { mampu } \\
\text { mengidentifikasi } \\
\text { berbagai bidang }\end{array}$ & $\begin{array}{l}\text { Kontribusi } \\
\text { Skil } \\
\text { Non-Skil }\end{array}$ \\
\hline & $\begin{array}{l}\text { Merencanakan } \\
\text { langkah kongkrit }\end{array}$ & $\begin{array}{l}\text { Raalitiski } \\
\text { Dampal }\end{array}$ \\
\hline
\end{tabular}

\section{Uji Validitas dan Reliabilitas}

\begin{tabular}{|c|c|c|c|c|}
\hline \multirow{2}{*}{ Variabel } & \multirow{2}{*}{$\begin{array}{l}\text { Jumlah } \\
\text { Item }\end{array}$} & \multicolumn{2}{|c|}{ ITEM PERTANYAAN } & \multirow{2}{*}{$\begin{array}{c}\text { Cronbach's } \\
\text { Alpha }\end{array}$} \\
\hline & & Valid & Un-Valid & \\
\hline $\begin{array}{l}\text { Edukasi } \\
\text { Orang Tua }\end{array}$ & 31 & $\begin{array}{r}1.2 .3 .4 \\
6.7 .8 .9 \\
10.11 .12 .13 \\
14.15 .16 .17 \\
18.19 .20 .21 \\
22.23 .24 .25 \\
26.27 .28 .29 \\
30.31\end{array}$ & 5 & 0.931 \\
\hline $\begin{array}{c}\text { Proses } \\
\text { Pengambilan } \\
\text { Keputusan } \\
\text { Karier }\end{array}$ & 40 & $\begin{array}{r}1.2 .3 .4 .5 \\
8.9 .10 .11 \\
12.13 .14 .16 \\
17.18 .19 .21 \\
23.24 .26 .27 \\
30.32 .33 .34 \\
35.37 .38 .39 \\
40\end{array}$ & $\begin{array}{r}6.7 .15 .20 \\
22.24 .25 \\
28.29 .31 \\
36\end{array}$ & 0.931 \\
\hline
\end{tabular}

\section{Teknik Analisis Data}

Dengan menganalisa data, dilakukan estimasi parameter model regresi yang akan digunakan. Dari persamaan regresi yang didapat, dilakukan pengujian atas regresi tersebut, agar persamaan yang didapat mendekati keadaan yang sebenarnya. Pengolahan data dalam penelitian ini menggunakan program SPSS 17.0. Adapun langkah-langkah dalam 
menganalisis data adalah sebagai berikut:

1. Uji Persyaratan Analisis

a. Uji Normalitas

Uji normalitas digunakan untuk mengetahui apakah populasi data berdistribusi normal atau tidak. Untuk mendeteksi apakah model yang peneliti gunakan memiliki distribusi normal atau tidak yaitu dengan menggunakan uji Kolmogorov Smirnov.

Hipotesis penelitiannya adalah:

1) $\mathrm{H}_{\mathrm{o}}$ : data berdistribusi normal

2) $\mathrm{H}_{\mathrm{a}}^{\circ}$ : data tidak berdistibusi normal

Kriteria pengujian dengan uji statistik Kolmogorov Smirnov yaitu:

1) Jika signifikansi $>0,05$, maka Hoditerima artinya data berdistribusi normal.

2) Jika signifikansi $<0,05$, maka Hoditolak artinya data tidak berdistribusi normal.

b. Uji Linearitas

Pengujian linieritas bertujuan untuk mengetahui apakah dua variabel secara signifikan mempunyai hubungan yang linier atau tidak. Pengujian dengan SPSS menggunakan Test of Linearity pada taraf signifikansi 0,05. Dua variabel dikatakan mempunyai hubungan yang linier bila nilai signifikansi pada linearity kurang dari 0,05 .

Hipotesis penelitiannya adalah:

1) $\mathrm{H}_{\mathrm{o}}$ : data tidak linear

2) $\mathrm{H}_{\mathrm{a}}$ : data linear

Sedang kriteria pengujian dengan uji statistik yaitu:

1) Jika signifikansi $>0,05$, maka Hoditerima artinya data tidak linear.

2) Jika signifikansi < 0,05, maka Hoditolak artinya data linear.

2. Korelasi sederhana

Untuk menghitung koefisien korelasi sederhana digunakan rumus Product Moment Pearson.

\section{Uji Hipotesis}

Uji $t$ digunakan untuk mengetahui pengaruh variabel independen secara parsial terhadap variabel dependen, apakah pengaruhnya signifikan atau tidak. Hipotesis penelitiannya:

$\mathrm{H}_{\mathrm{a}}$ Ada ada hubungan antara Aspirasi Edukasi Orang Tua terhadap Proses Pengambilan Keputuan Karier Siswa SMA 36 Jakarta

\section{Analisis dan Pembahasan}

\section{A. Deskripsi Data}

1. Identifikasi Responden

\begin{tabular}{|c|c|c|c|c|c|}
\hline \multicolumn{2}{|c|}{ URAIAN } & \multicolumn{2}{c|}{ Frekuensi } & \multicolumn{2}{c|}{ Prosentase } \\
\cline { 3 - 6 } & & P & W & P & W \\
\hline \multirow{3}{*}{ Usia } & 15 Th & 3 & 6 & $4 \%$ & $8 \%$ \\
& 16 Th & 32 & 15 & $43 \%$ & $20 \%$ \\
& 17 Th & 17 & 2 & $23 \%$ & $3 \%$ \\
\hline \multirow{3}{*}{ Kepeminatan } & IPA & 7 & 17 & $9 \%$ & $23 \%$ \\
& IPS & 13 & 9 & $17 \%$ & $12 \%$ \\
& BHS & 11 & 0 & $15 \%$ & $0 \%$ \\
\hline
\end{tabular}

\section{Deskripsi Statistik}

\begin{tabular}{|l|c|c|}
\cline { 2 - 3 } \multicolumn{1}{c|}{} & $\begin{array}{c}\text { Aspirasi } \\
\text { Edukasi } \\
\text { Orang Tua } \\
\left(\mathbf{Y}_{\mathbf{1}}\right)\end{array}$ & $\begin{array}{c}\text { Proses } \\
\text { Pengambilan } \\
\text { Keputusan } \\
\text { Karier }\left(\mathbf{Y}_{\mathbf{2}}\right)\end{array}$ \\
\hline Mean & 93.2933 & 98.7067 \\
Median & 93.0000 & 99.0000 \\
Mode & 103.00 & 104.00 \\
Std. Deviation & 12.40289 & 10.61459 \\
Variance & 153.832 & 112.670 \\
Skewness & -.062 & -.279 \\
Kurtosis & -.325 & -.113 \\
Range & 57.00 & 47.00 \\
Minimum & 67.00 & 72.00 \\
Maximum & 124.00 & 119.00 \\
Sum & 6997.00 & 7403.00 \\
\hline
\end{tabular}

a. Aspirasi Eduksi Orang Tua

Dari deskripsi data variabel Aspriasi edukasi orang tua dengan menggunakan 75 orang siswa, terlihat tidak ada data hilang (missing) dengan nilai kumulatif atas varaibel sebesar 6997 di mana nilai rata-rata atas variabel ini sebesar 93, adapun nilai tengah (median) atas data sebesar 93, untuk data yang sering muncul (mode) sebesar 103 di mana nilai simpangan baku atas data (standar deviasi) sebesar 12,4 dan variasi data (variance) sebesar 153,8 dimana titik landai (skewness) sebesar -0.062 dimana titik puncak (kurtosis) sebesar -0.325 dengan jarak data (range) sebe- 
sar 57 dengan nilai tertinggi sebesar 124 adapun data terendah sebesar 67, sehingga interval pada variabel Aspraisi Edukasi orang Tua (Y1) dapat dilihat sebagai berikut :

1) Rentang Kelas :

Data terbesar - Data terkecil

$$
\begin{aligned}
& =124-67 \\
& =57
\end{aligned}
$$

2) Banyak Kelas:

$$
\begin{array}{ll} 
& 1+(3,3) \cdot \text { Log.n } \\
= & 1+(3,3) \cdot 75 \\
= & 1+(3,3) \cdot 1,87 \\
= & 1+6 \cdot 17 \\
= & 7,17(7)
\end{array}
$$

3) Panjang Interval :

\begin{tabular}{|c|c|c|c|c|}
\hline $\begin{array}{c}\text { Interval } \\
\text { Kelas }\end{array}$ & $\begin{array}{l}\text { Batas } \\
\text { Bawah }\end{array}$ & $\begin{array}{l}\text { Batas } \\
\text { Atas }\end{array}$ & Frekuensi & $\begin{array}{l}\text { Frek. } \\
\text { Relatif }\end{array}$ \\
\hline $67-74$ & 67 & 74.5 & 7 & 9.33 \\
\hline $75-82$ & 74.5 & 82.5 & 7 & 9.33 \\
\hline $83-90$ & 82.5 & 90.5 & 17 & 22.66 \\
\hline 91 - 98 & 90.5 & 98.5 & 10 & 13.33 \\
\hline $99-106$ & 98.5 & 106 & 23 & 30.66 \\
\hline $107-114$ & 106.5 & 114.5 & 7 & 9.33 \\
\hline $115-124$ & 114.5 & 124 & 2 & 2.66 \\
\hline \multicolumn{3}{|c|}{ Jumlah } & 75 & $100 \%$ \\
\hline
\end{tabular}

$$
\begin{aligned}
& \frac{\text { Rentang Kelas }}{\text { Kelas }} \\
= & 57 / 7 \\
= & 8.1(8)
\end{aligned}
$$

Distribusi frekuensi dari data Aspirasi Edukasi Edukasi Orang Tua dengan riancian distrubusi frekuensi sebagai berikut :

Distribusi Frekuensi Aspirasi Edukasi Edukasi Orang Tua

b. Proses Pengambilan Keputusan Karier

Pengambilan keputusan yang dilakukan oleh remaja sama pentingnya dengan pengambilan keputusan yang dilakukan oleh dewasa. Keputusan pengambilan jurusan sangat berpengaruh terhadap masadepan siswa, hal ini merupakan awal dari pengambilan keputusan karier, karenanya remaja atau siswa SMA sudah seha- rusnya dapat mengambil keputusan yang tepat, karena akan mempengaruhi masa depan mereka. Namun,seringkali remaja merasa bingung dan bimbang dengan pilihan karier, Dari deskripsi data variabel Proses Pengambilan Keputusan Karier (Y2) dengan menggunakan 75 orang siswa, terlihat tidak ada data hilang (missing) dengan nilai kumulatif atas varaibel sebesar 7403 dimana nilai rata-rata atas variabel ini sebesar 98.70, adapun nilai tengah (median) atas data sebesar 99, untuk data yang sering muncul (mode) sebesar 104 dimana nilai simpangan baku atas data (standar deviasi) sebesar 10,6 dan variasi data (variance) sebesar 112,6 dimana titik landai (skewness) sebesar -0.279 dimana titik puncak (kurtosis) sebesar -0.111 dengan jarak data (range) sebesar 47 dengan nilai tertinggi sebesar 119 adapun data terendah sebesar 72, sehingga interval pada variabel Proses Pengambilan Keputusan Karier (Y2) dapat dilihat sebagai berikut :

1). Rentang Kelas:

Data terbesar - Data terkecil

$$
\begin{aligned}
& =119-72 \\
& =47
\end{aligned}
$$

2). Banyak Kelas :

$$
\begin{array}{ll}
= & 1+(3,3) \cdot \log \cdot n \\
= & 1+(3,3) \cdot 75 \\
= & 1+(3,3) \cdot 1,87 \\
= & 1+6 \cdot 17 \\
& 7,17(7)
\end{array}
$$

3). Panjang Interval :

$$
\begin{aligned}
& \frac{\text { Rentang Kelas }}{\text { Kelas }} \\
= & 47 / 7 \\
= & 6.7
\end{aligned}
$$

Distribusi frekuensi dari data Proses Pengambilan Keputusan Karier dapat dilihat pada tabel distribusi di bawah ini, di mana rentang skor yang dimiliki adalah 47, memiliki banyak kelas interval sebesar 7.17 yang dibulatkan menjadi 7 dengan panjang kelas intervalnya sebesar 7 yang dibulatkan menjadi 7. 
Distribusi Frekuensi Keputusan karier

\begin{tabular}{|c|c|c|c|c|}
\hline $\begin{array}{l}\text { Interval } \\
\text { Kelas }\end{array}$ & $\begin{array}{c}\text { Batas } \\
\text { Bawah }\end{array}$ & $\begin{array}{l}\text { Batas } \\
\text { Atas }\end{array}$ & Frekuensi & $\begin{array}{l}\text { Frek. } \\
\text { Relatif }\end{array}$ \\
\hline $72-78,6$ & 72 & 78.7 & 4 & $5.33 \%$ \\
\hline $78,7-85,3$ & 78.7 & 85.4 & 2 & $2.66 \%$ \\
\hline $85,4-92,0$ & 85,4 & 92.1 & 13 & $17.33 \%$ \\
\hline $92,1-98,7$ & 92.1 & 98.8 & 18 & $24.00 \%$ \\
\hline $98,8-105,4$ & 98.8 & 105.5 & 19 & $25.33 \%$ \\
\hline $105,5-112,1$ & 105.5 & 112.2 & 9 & $12.00 \%$ \\
\hline $112,2-119$ & 112.2 & 119.5 & 10 & $13.33 \%$ \\
\hline \multicolumn{3}{|c|}{ Jumlah } & 75 & $100 \%$ \\
\hline
\end{tabular}

\section{Uji Normalitas}

Pengujian data dengan menggunakan uji homogenitas dengan menggunakan uji Klomogorov-Smirnov dihasilkan data seperti pada Tabel berikut:

\begin{tabular}{|c|c|c|}
\hline & $\begin{array}{c}\text { Aspirasi } \\
\text { Edukasi Orang } \\
\text { Tua (Y1) }\end{array}$ & $\begin{array}{c}\text { Proses } \\
\text { Pengambilan } \\
\text { Keputusan } \\
\text { Karier (Y2) }\end{array}$ \\
\hline $\begin{array}{c}\text { Asymp. Sig. } \\
(2 \text { - tailed) }\end{array}$ & .392 & .968 \\
\hline
\end{tabular}

Berdasarkan hasil pengolahan data pada variabel Aspirasi Edukasi Orang tua dengan nilai Asymp. Sig $0.392>\alpha=0.05$ maka distribusi variabel Aspirasi edukasi orang tua dinyatakan normal. Nilai variabel proses pengambilan keputusan karier dengan nilai Asymp.Sig $0.968>\alpha=0.05$ maka distribusi variabel Pross pengambilan keputusan karier dalam kondisi normal. Karena keseluruhan variabel dinyatakan normal maka varaibel Pross pengambilan keputusan karier dapat di uji fungsi hubungan antar vairabel

\section{Uji heteroskedastisitas}

Uji heteroskedastisitas digunakan untuk menguji apakah dalam sebuah model regresi terjadi ketidaksamaan varian dari residual suatu pengamatan kepengamatan yang lain. Jika varian dari residual dari suatu pengamatan kepengamatan yang tetap maka disebut homoskedastisitas, namun apabila variabel berbeda disebut heteroskedastisitas. Model regresi linier yang baik adalah tidak mengalami heteroskedastisitas. Penulis telah melakukan perhitungan dan mendapatkan hasil sebagai berikut :

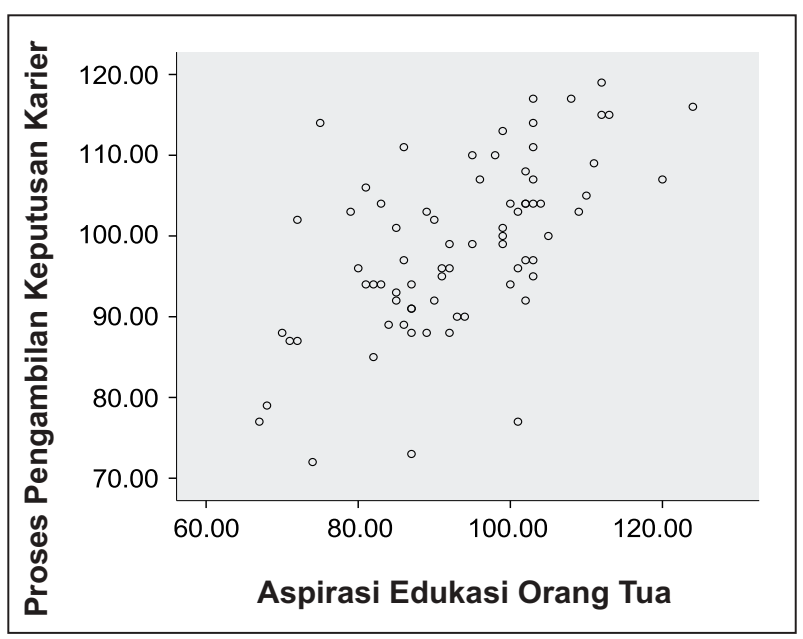

Untuk mengetahui apakah menunjukkan adanya heteroskedastisitas adalah apabila titik-titik pada grafik membentuk suatu pola tertentu yang dapat ditarik satu garis lurus. Bila mencermati pola sebaran data menujukan bahwa pada kondisi apresiasi orang tua rendah sedangkan proses pengambilan keputusan siswa rendah cukup banyak pola sebaran pada kondisi ini, namun bila mencermiati apreasi edukasi orang tua rendah namun pengambilan keputusan siswa tinggi dengan pola sebaran data yang cukup banyak dan pada struktur pola sebaran data dengan kondisi aspriasi edukasi orang tua tinggi dan menerminkan pengambilan keputusan tinggi terlihat pola sebaran juga rerlatif tinggi. Namun secar aumum pada grafik yang muncul di atas terlihat bahwa titik-titik pada grafik menyebar dan tidak membentuk suatu pola, maka dapat disimpulkan bahwa penelitian tidak mengalami heteroskedastisitas.

\section{B. Analisis}

Hasil pengolahan data antara variabel Aspirasi Eduksi Orang Tua dengan Proses Pengambilan Keputusan Karier

\section{Analisis Korelasi}

Dari hasil pengolahan data terlihat bahwa nilai korelasi sebesar 0,601 dengan demikian ada hubungan positif kuat antar variabel, artinya bila variabel Aspriasi edukasi orang tua (X) meningkat atau ditingkatkan maka akan diikuti penguatan variabel pengambilan keputusan karier siswa $(\mathrm{Y})$ 


\begin{tabular}{|c|l|c|c|}
\hline \multirow{2}{*}{$\begin{array}{c}\text { Pearson } \\
\text { Correlation }\end{array}$} & $\begin{array}{l}\text { Proses } \\
\text { pengambilan } \\
\text { keputusan } \\
\text { karier }\end{array}$ & $\begin{array}{c}\text { Proses } \\
\text { pengambilan } \\
\text { keputusan } \\
\text { karier }\end{array}$ & $\begin{array}{c}\text { Aspirasi } \\
\text { edukasi } \\
\text { orang tua }\end{array}$ \\
\cline { 2 - 4 } & $\begin{array}{l}\text { Aspirasi } \\
\text { edukasi orang } \\
\text { tua }\end{array}$ & 1.000 & .601 \\
\hline \multirow{2}{*}{$\begin{array}{l}\text { Sig. (1- } \\
\text { tailed) }\end{array}$} & $\begin{array}{l}\text { Proses } \\
\text { pengambilan } \\
\text { keputusan } \\
\text { karier }\end{array}$ & .601 & 1.000 \\
\cline { 2 - 4 } & $\begin{array}{l}\text { Aspirasi } \\
\text { edukasi } \\
\text { orang tua }\end{array}$ & -000 & \\
\hline
\end{tabular}

Hasil uji koefisien determinan sebesar 0,361 [ r $2 \times 100 \%$ atau $(0,601) 2 \times 100 \%=361 \%$ ] dengan demikian variasi peningkatan atau penurunan variable Proses Pengambilan Keputusan Karier (Y) dapat dijelaskan oleh variable Aspriasi Edukasi Orang Tua sebesar $36.1 \%$ sehingga faktor lain diluar kedua variable sebesar $63.9 \%$ dan hal tersebut tidak dijelaskan lebih lanjut dalam penelitian ini.

\section{Regresi Linear}

\begin{tabular}{|c|c|c|c|c|c|}
\hline \multicolumn{3}{|c|}{$\begin{array}{l}\text { Unstandardized } \\
\text { Coefficients }\end{array}$} & \multicolumn{3}{|c|}{$\begin{array}{l}\text { Standardized } \\
\text { Coefficients }\end{array}$} \\
\hline Model & B & $\begin{array}{l}\text { Std. } \\
\text { Error }\end{array}$ & Beta & $\mathrm{t}$ & Sig. \\
\hline (Constant) & 50.719 & 7.533 & & 6.733 & .000 \\
\hline $\begin{array}{c}\text { Aspirasi edukasi } \\
\text { orang tua }\end{array}$ & .514 & .080 & .601 & 6.425 & .000 \\
\hline
\end{tabular}

\section{$\hat{Y}=50,719+0,514 X$}

Nilai constanta sebesar 50,719 menunjukan nilai murni variable Proses pengambilan keputusan karier Siswa/i SMA Negeri 36 Jakarta Timur. Nilai regresi sebesar 0,514 menunjukkan ada kontribusi positif dihasilkan oleh variable Aspriasi edukasi orang tua siswa, artinya bila variabel $\mathrm{X}$ naik atau ditingkatkan sebesar 1 point maka akan diikuti penguatan pada variable Proses peng-ambilan keputusan karier siswa (Y) sebesar 1 point.

\section{Uji Hipoitesis Individual}

Hasil uji hipotesis terlihat bahwa nilai thitung sebesar 6,425 dimana ttabel sebesar 1,980 dengan demikian (thitung 6,425 > ttabel 1,980) maka (Ho) ditolak dan (Ha) diterima artinya ada hubungan antara Aspriasi Edukasi Orang Tua (X) dengan Proses Pengambilan Keputusan Karier (Y).

Nilai probabilitas hasil terlihat $(\rho=0,000<$ $\alpha=0,05$ ) dengan demikian variable Aspriasi Edukasi Orang Tua (X) dinyatakan signifikan terhadap Proses Pengambilan Keputusan Karier (Y)., sehingga hipotesis penelitian diterima, artinya variable Aspriasi Edukasi Orang Tua dapat dijadikan tolok ukur terhadap Proses Pengambilan Keputusan Karier.

\section{Interprestasi Data}

Berdasarkan hasil pengolahan data antara variabel independen dengan variabel dependen dalam hal ini Aspriasi edukasi orang tua (X) dengan pengambilan keputusan karier siswa (Y) dihasilkan korelasi sebesar 0,601 dengan demikian ada hubungan positif kuat antar variabel, artinya bila variabel Aspriasi edukasi orang tua (X) meningkat atau ditingkatkan maka akan diikuti penguatan variabel pengambilan keputusan karier siswa (Y), di mana nilai persamana regresi $\hat{Y}=50,719+0,514 X$ menujukan bahwa nilai murni atas variabel Proses pengambilan keputusan karier Siswa/i SMA Negeri 36 Jakarta Timur sebesar 50.719 sedangkan kontribusi variabel aspriasi edukasi orang tua sebesar 0,514 hasil uji hipotesis terlihat thitung 6,425 $>t$ tabel 1,980 maka $\left(\mathrm{H}_{\mathrm{a}}\right)$ diterima dengan $\rho=0,000<\alpha=0,05$ dengan demikian variable Aspriasi Edukasi Orang Tua (X) dinyatakan signifikan terhadap Proses Pengambilan Keputusan Karier (Y), sehingga hipotesis penelitian diterima, artinya variable Aspriasi Edukasi Orang Tua dapat dijadikan tolok ukur terhadap Proses Pengambilan Keputusan Karier.

Pada pengujian hipotesis pertama sejalan dengan teori yang dibangun bahwa Aspirasi mempunyai hubungan yang sangat erat dengan keinginan yang dimiliki oleh setiap orang, Keinginan yang dimiliki bukan hanya untuk masa kini, tetapi juga menyangkut masa depannya. Dengan adanya keinginan tersebut seseorang akan termotivasi dan berusaha untuk meraih segala sesuatu yang diinginkan- 
nya. Sebagai contoh bila individu (orangtua) mengetahui secara nyata kondisi dari lingkungan dan keseluruhan dari sekolah yang dituju maka orangtua akan menyampaikan informasi secara (transformasi pengetahuan) bertahap kepada apa dan bagaimana kondisi dari sekolah sehingga siswa dapat mengetahui secara naturan dan menerima informasi bukan pada situasi pelaksanaan atau penekanan.

Aspirasi merupakan tujuan yang ditetapkan oleh individu berkaitan dengan suatu tugas yang mempunyai arti penting bagi dirinya atau menuntut pelibatan individu sepenuhnya arti pencapaian tujuan yang telah ditetapkan oleh individu memerlukan usaha yang maksimal dari individu . Banyak orang tua menjadi orangtua tanpa mengalami persiapan untuk menjadi orang tua. Kebanyakan orangtua hanya menjadi orang tua berintikan naluri saja, tanpa mempersiapkan diri untuk menjadi seorang ayah atau seorang ibu Banyak cara mendidik mengikuti pola pendidikan yang dialaminya dengan kemungkinan hasil yang dijadikannya sama diterapkan pada zaman yang berbeda.

Orangtua ingin siswa bisa dibanggakan dari semua aspek. Siswa akan belajar dari latihan-latihan dasar mengembangkan sikap-sikap sosial yang baik, kebiasaan-kebiasaan bertingkah laku yang memudahkan terbentuknya perilaku tanpa keraguan, tanpa pertarungan motif dan konflik yang terlalu lama di mana: (1) Dalam ikatan keluarga yang akrab dan hangat, seorang siswa yang memperoleh pengertian tentang hak, kewajiban, tanggung jawab yang diharapkan.

Dalam keluarga siswa belajar mengenai kewibawaan dan sikap otoriter dari yang lebih tua. Siswa belajar mematuhi peraturan, tata cara keluarga. Mungkin juga terjadi penyalahgunaan otoritas, dimana orang tua yang terlalu ketat mengakibatkan berkurangnya dinamika siswadalam mengembangkan kemampuan dan kepribadiannya. Di dalam keluarga di mana ada hubungan yang baik antara anggotanya, siswa belajar bekerjasama, membagi rasa kepada yang lainnya, selalu ingat akan adanya saudara-saudara sehingga membentuk sikap-sikap sosial yang memudahkan hubungan sosial. Seorang siswa dalam keluarga terlihat ikatan keluarga yang diwarnai kehangatan dan keakraban akan membentuk azas hidup berkelompok yang baik sebagai lan- dasan hidupnya di masyarakat. (2) Bilamana menghadapi seseorang dalam pergaulan yang santai dan menganggap hidup itu selalu membahagiakan, akan diketahui bahwa latar belakang kehidupan keluarganya, menyebabkan ia selalu melihat sisi positif dalam kehidupannya. Sebaliknya seseorang yang selalu tegang dan pesimis dalam pandangan hidupnya, disebabkan latar belakang keluarganya yang dikuasai oleh suasana suram .

Terhadap hipotesis kedua menunjukkan hubungan yang harmonis dan interaksi yang baik antar orang tua dengan anak membantu remaja dalam mengambil keputusan karier mereka. Bagi siswa SMA, pengambilan keputusan karir yang termasuk penting adalah keputusan untuk memilih prog-ram studi, sedangkan pada saat itu banyak siswa yang belum memunyai kematangan untuk itu .

Belum matangnya putusan pilihan program studi di antara siswa dapat disebabkan oleh faktor-faktor internal dan eksternal. Faktor-faktor eksternal antara lain keluarga dan sekolah. Proses perkembangan karir remaja sering mengalami hambatan. Masalah yang berasal dari dalam dirinya antara lain ketidak yakinan individu terhadap kemampuan yang dimiliki untuk mencapai suatu hasil atau pilihan karir yang diinginkan dan masalah yang berasal dari luar atau lingkungan antara lain sering terjadi orang tua yang memaksa anaknya untuk memilih jurusan pendidikan yang mempersiapkan pada pekerjaan tertentu tetapi tidak sesuai dengan kemampuan anak. Yang lebih parah lagi kalau terjadi pilihan anak dan pilihan orang tua tidak saling mendukung, maka anak menghadapi konflik yang lebih serius lagi dalam memilih karir.

Menurut teori pengambilan keputusan karier yang di kemukakan Holland's dari dengan asumsi mengenai pilihan karier yangdiekspresikan atau diungkapkan melalui kepribadian seseorang; pilihan pekerjaan merupakan penggambaran aspriasi seseorang yang terlihat pada motivasi, pengetahuan, kepribadian dan kemampuan. Jadi yang dimaksud dengan pengambilan keputusan karir adalah suatu proses sistematis mengenai pilihan karir yang telah ditetapkan individu dari berbagai data yang digunakan dan dianalisa berdasarkan ekspresi atau ungkapan diri yang terlihat pada motivasi, pengetahuan, kepribadian dan kemampuan. 


\section{Keterbatasan Penelitian}

Berdasarkan hasil pengolahan data menujukan bahwa terdapat pengaruh positif signifikan antara Aspirasi edukasi orang tua terhadap proses pengambilan keputusan karier dinyatakan signifikan, namun dari hasil pengujian masih terdapat faktor lain diluar kedua variabel yang cukup besar dengan demikian kiranya penelitain ini memiliki keterbatasan sebagai berkut:

1. Kelemahan penelitian ini belum mewakili secara komprehensif siswa SMA Negeri 36 Jakarta, sehingga untuk penyempurnaan perlu dilakukan penelitian secara menyeluruh pada keseluruhan siswa

2. Waktu dalam penelitian relatif terbatas, mengingat keterbatasan waktu tersebut ditekankan oleh pihak sekolah, penelitian tidak dapat dilakukan secara personal, yang berdampak sulinya memahami kondisi secara mendalam semua aspek yang ditanyakan pada siswa/siswi atau narasumber.

\section{Kesimpulan, Implikasi, dan Saran A. Kesimpulan}

Berdasarkan hasil pengolahan data antara variabel independen dengan variabel deoen den dalam hal ini Aspriasi edukasi orang tua $(\mathrm{X})$ dengan pengambilan keputusan karier siswa (Y) dihasilkan korelasi sebesar 0,601 dengan demikian ada hubungan positif kuat antar variabel, artinya bila variabel Aspriasi edukasi orang tua $(\mathrm{X})$ meningkat atau ditingkatkan maka akan diikuti penguatan variabel pengambilan keputusan karier siswa (Y), dimana nilai persamana regresi $\hat{Y}=50,719+0,514 \mathrm{X}$ menujukan bahwa nilai murni atas variabel Proses pengambilan keputusan karier Siswa/i SMA Negeri 36 Jakarta Timur sebesar 50.719 sedangkan kontribusi variabel aspriasi edukasi orang tua sebesar 0,514 hasil uji hipotesis terlihat thitung 6,425>ttabel 1,980 maka (Ha) diterima dengan $\rho=0,000<\alpha=0,05$ dengan demikian variable Aspriasi Edukasi Orang Tua (X) dinyatakan signifikan terhadap Proses Pengambilan Keputusan Karier (Y)., sehingga hipotesis penelitian diterima, artinya variable Aspriasi Edukasi Orang Tua dapat dijadikan tolok ukur terhadap Proses Pengambilan Keputusan Karier.

\section{B. Implikasi}

Hasil uji koefisien determinan sebesar 0,361 dengan demikian variasi peningkatan atau penurunan variable Proses Pengambilan Keputusan Karier Siswa 36 Jakarta Timur dapat dijelaskan oleh variable Aspirasi Eduksi Orang Tua Sekolah sebesar 36.1\% sehingga faktor lain diluar kedua variable sebesar $63.8 \%$ dengan demikian ada faktor-faktor lain diluar kedua variabel yang cukup besar dengan demikian perlu ada penelusuran lebih mendalam brkenaan dengan faktor-faktro lain di luar kedua varirabel

\section{Saran}

Berdasarkan hasil pengolahan data dan kesimpulan penelitain maka saran-saran atas hasil penelitain adalah:

1. Terhadap variabel Aspriasi Edukasi Orang Tua hal yang perlu mendapat perhatian adalah pada dimensi minat dengan demikian bimbingan konseling perlu memberikan penekanan pada siswa/ peswerta didik berkenaan dengan menggali kemampuan dan pengetahuan pesetra didik berkenaan dengan pilihan bidang studi, memotivasi anak untuk memilih; memilih dan mengikuti serta menentukan kegiatan belajar hal ini dapat dilakukan dengan kegaitan konseling personal maupun kelompok.

2. Untuk variabel proses pengambilan keputusan hal yang perlu mendapat perhatian adalah dengan mendeskripsikan dengan menggali pemahaman atas kepemintan serta mempersiapkan peserta didik untuk dengan membentuk keperibadian mereka

\section{Daftar Pustaka}

A. Muri Yusuf.2008, Kiat Sukses Dalam Karir. Ghalia Indonesia.

As'ad, Muhammad.2007. Psikologi Industri : Seri Ilmu SDM.. Yogyakarta : Liberty,

Alwisol.2009, Psikologi kepribadian (revisi ed.). Malang: UMM Press.

A.Muri Yusuf,2008. Konseling Karier dalam Satuan Pendidikan dan Praktik Pribadi, (Makalah). Padang, Universitas Negeri Padang. 2008

Colly H,.2005, Do We Choose Careers or Do They Choose Us; Questions About Career Choice, Transitions, and Social Inculusion, Vejleder Forum, 4,5-50 
Charles E Lamb.2007, Richard S. Crutchfield and Edgerton L Bellyache, Individual in Soriaty : A text book of Social Psichology, New York : Mc Graw Hill Book Co,

Charles E Lamb, Richard S, 2001. Crutchfield and Edgerton L Bellyache, Individual in Soriaty : A text book of Social Psichology, New York : Mc Graw Hill Book Co,

Dayakisni,T. dan Hudaniah.2009. Psikologi sosial. Malang: UMM Press.

Derlega, V., Metts S.2007, Petronio S \& Margulis S.T. Self disclosure. California: Sage Publication. Inc.

Dewa Ketut Sukardi,2000. Bimbingan karir di sekolahsekolah.Jakarta: Ghalia Indonesia.

Djuarsa, S. Sendjaja.2006. Teori Komunikasi. Jakarta : Pusat Penerbit UT,

Djaali, dkk.2000, Pengukuran Dalam Bidang Pendidikan, Jakarta: Program Pasca Sarjana Universitas Negeri Jakarta.

Djaali, dkk.2000, Pengukuran Dalam Bidang Pendidikan, Jakarta: Program Pasca Sarjana Universitas Negeri Jakarta,

Duwi Priyatno.2011, SPSS Analisis Statistik Data Lebih Cepat, Efisien dan Akurat., Jakarta: MediaKom.

Dep. P dan K.2000, Petunjuk Pelaksanaan Bimbingan Karier,

Edwin L. Herr, and Stenley H.Cramer.2006, Career Guidance and Counseling Trough the Life Span, Systematic Approuches, New York, Harper Collins Publisher.

Elizabeth B., Hurlock.2004, Child Development, Singapore : Mc Graw Hills Books Co,
Effendi, Usman.2009. Kumunikasi dalam Pendekatan Psikologi. Bandung : Alfa Betta.

Fauzi, Ahmad. 2007. Psikologi Umum. Jakarta : Pustaka Setia,

Gunarsa D. Singgih dan Ny Y Singgih Gunarsa.2008, Psikologi Praktis ; Anak, Remaja dan Keluaga., BPK Gunung Mulia Jakarta.

Hartinah, Siti. 2010. Pengembangan Peserta Didik .Bandung: PT Rafika Aditama.

Hartinah, Siti. 2010. Pengembangan Peserta Didik .Bandung: PT Rafika Aditama.

Koeswara, E.2005, Teori-teori kepribadian, PT Eresco, Bandung.

Leislie L.Kanuk dan Leon Schiffman G.2004. The Craft of Teaching. San Francisco : Jossey Bass Publishers,

Munandir.2006, Kamus Psikologi Dan Bimbingan. Malang : Universitas Negeri Malang,

Mohammad Manrihu, Thayeb. 006. Pengantar Bimbingan dan Konseling Karir. Jakarta: BumiAksara, hlm 34

Miftah, Thoha. 2008. Perilaku Organisasi, Konsep dan Aplikasinya. Jakarta : PT.Raja Grafindo.

Prihadhi, Endra.2009 My Potential. Jakarta elex Media Komputindo Kelompok Gramedia,

Prayitno.2008, Pedoman Pelaksanaan Pelayanan Konseling pada Satuan Pendidikan Dasar dan Menengah. Padang: UNP.

Prihadhi, Endra My Potential.2009. Jakarta elex Media Komputindo Kelompok Gramedia, 